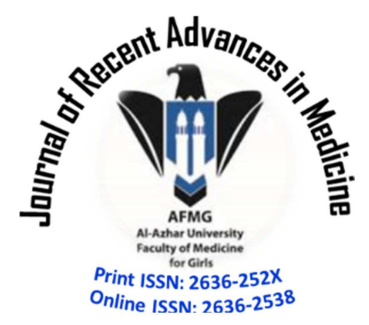

Original Article

\title{
The role of detection of anti-HBc IgM in HBs Ag negative blood donors
}

\author{
Marwa I. Hasssan ${ }^{1}$, Saffeia A. El Gamal ${ }^{1}$, Aml E. Abdou $^{1 *}$, Dalia M. Eldewi ${ }^{2}$ \\ ${ }^{1}$ Department of Microbiology and Immunology, Faculty of Medicine for Girls, Cairo, Al-Azhar University, Egypt \\ ${ }^{2}$ Department of Clinical Pathology, Faculty of Medicine for Girls, Cairo, Al-Azhar University, Egypt.
}

\begin{abstract}
Background: Post Transfusion hepatitis B viral infection is a major problem even after adoption of mandatory screening test, HBsAg by ELISA test in blood banks. In Egypt, HBsAg is the only HBV screening test of blood donors in most bloods banks. However HBsAg negative blood donors does not rule out the risk of transmission of hepatitis B, as the donor may be in the 'window period' or has a mutant strain. During this period, detection of the antibody to the hepatitis B core antigen (anti-HBc) IgM type is a useful serological marker.
\end{abstract}

Objective: this study aimed to evaluate the significance of screening anti-HBc IgM for HBsAg negative blood donors to reduce the risk of transfusion transmitted HBV infection in Egypt.

Methodology: Four hundred HBsAg negative blood donors were randomly selected from Al-Zahraa University hospital blood bank, for further screening by anti-HBcIgM by ELISA test, then positive samples for anti-HBcIgM were tested for HBV DNA by PCR.

Results: Nine (2.25\%) out of selected 400 samples were positive for anti-HBcIgM, and 4 (1\%) out of these 9 samples

Conclusion: Anti HBcAg IgM screening test should be implemented as an additional screening test for blood donors in Egypt, to improve transfusion safety as it is an indicator of occult HBV during window period.

JRAM 2020; 1(2): 67-74

Keywords: HbsAg, anti HBc IgM, HBV DNA, window period.

Submission date : 18 December 2019

Acceptance Date: 26 February -2-2020

Corresponding Author: Aml El-Sayed Abdou, Department of Microbiology and Immunology, Faculty of Medicine (for girls), Al-Azhar University, Egypt. Tel.: 01112323539. E-mail: amlelsayed@ azhar.edu.eg.

Please cite this article as: Hasssan $\mathrm{MI}^{1}$, El Gamal SA, Abdou AE, Eldewi AM. The role of detection of anti-HBc IgM in HBs Ag negative blood donors. JRAM 2020; 1(2): 67-74. DOI: 10.21608/jram.2020.19827.1020

\section{INTRODUCTION}

Hepatitis B is a life-threatening liver infection caused by the hepatitis $\mathrm{B}$ virus (HBV). It is one of the major global health problems especially in highly endemic areas [1]. It occurs worldwide, up to two billion, approximately $30 \%$ of the world's populations, have serological evidence of past or present HBV infection ${ }^{[2]}$. Despite the availability of a highly efficient vaccine and potent antiviral agents, the burden of the disease is increasing as almost $45 \%$ of the global population live in developing regions with high prevalence $(>8 \%)$ of chronic HBV infection, where vaccination of large populations has not been possible due to economic reasons ${ }^{[3] .} \mathrm{HBV}$ infection can induce a wide spectrum of clinical features, ranging from an inactive carrier state, acute to fulminate hepatitis, or chronic infection to cirrhosis or hepatocellular carcinoma (HCC) ${ }^{[2] .}$
Chronically infected people represent about 257 million and about $5 \%$ of these are at risk of developing the squeal of chronic HBV infection ${ }^{[4]} \mathrm{HBV}$ infection is one of the major risk factors for the development of HCC in the world. Most of the burden of the disease (85\%) is observed in highly endemic regions. HCC is the sixth most common cancer in the world and the second leading cause of cancer death ${ }^{[5]}$ Death resulting from HBV, stands for about 1.34 million deaths annually. Most of these due to liver cirrhosis, liver failure and $\mathrm{HCC}{ }^{[6]}$ As blood transfusion is an important route of $\mathrm{HBV}$ transmission; it is recommended that all donated blood should be screened for $\mathrm{HBV}$ before transfusion to prevent post-transfusion hepatitis. Screening of donated blood is by hepatitis B surface antigen (HBsAg), which was introduced in the 1970s and this greatly reduced post- transfusion hepatitis [7]. However, negative HBsAg of apparently healthy donor's dose not exclude HBV 
infection and HBV is still the highest risk among transfusion-transmitted diseases ${ }^{[8] \text {. }}$

There are various clinical conditions at which $\mathrm{HBsAg}$ is negative, although there is HBV infection. These conditions include the window period, low viral level after recovery and escape mutants. The presence of HBV-DNA in blood or liver tissues in patients negative for HBsAg with or without HBV antibodies is known as Occult HBV infection (OBI). It represents a carrier state of the disease and a definite hazard of transmission of HBV to recipients ${ }^{[9] .}$ Finding a marker that can detect $\mathrm{HBV}$ infection in HBsAg negative cases is very important to be implemented in blood banks to diagnose these cases. It was found that antibody to the hepatitis B core antigen is more effective for diagnosing $\mathrm{HBV}$ in these cases ${ }^{[10]}$ Hepatitis B core antigen consists of two classes, IgM and IgG. IgM (anti-HBcIgM) is the first antibody to appear and indicates a recent infection, while the IgG class appears later during the infection and indicates past HBV infection or recovery. Individuals with anti-HBc IgG may not be infectious as they may have high titers of antibodies to $\mathrm{HBs} \mathrm{Ag}$, which are protective in nature. So the IgM class of the anti-HBc is more effective marker for $\mathrm{HBV}$ infection in $\mathrm{HBs} \mathrm{Ag}-\mathrm{ve}$ cases [11]. PCR technique is important in diagnosis of these conditions, however if HBV DNA testing is not feasible, detection of anti-HBc, mainly IgM class, is a useful serological marker for $\mathrm{HBV}$ infection in these cases ${ }^{[12] .}$

\section{SUBJECT AND MEDODS}

\section{Study population}

The present study was carried out on four hundred voluntary blood donors, 352 males (88 \%) and 48 were females $(12 \%)$ with average age from 20 to 50 years old. Samples are collected from the blood bank of Al-Zahra University Hospital from November 2017 to May 2018. The study was held in the microbiology department of Faculty of Medicine (for girls), Al-Azhar University (Cairo, Egypt) and immunity section of clinical pathology department of Al Zahra University Hospital. Verbal informed consent was obtained from all donors. The approval from the Research Ethics Committee of the faculty of medicine, Al-Azhar University was also obtained.

The following was done of all subjects in the study:

1. The blood donors were selected after they fulfilled the mandatory criteria for donation eligibility as guidelines for blood banks (age, sex, and nationality) are recorded.

2. All samples were negative for all screening tests that done in blood banks (HBV, HCV, HIV and malaria).

\section{Inclusion criteria:}

Age above 18 years old, both sexes and their blood thought to be safe for transfusion after screening (negative for $\mathrm{HbsAg}$, negative $\mathrm{HCV}$ antibodies, negative HIV and malaria).

\section{Exclusion criteria}

Age below 18 years old, positive blood samples for HBV, HCV, HIV or malaria.

\section{Samples:}

1. At the time of blood donation, $5 \mathrm{ml}$ of venous blood was drawn aseptically by venipuncture and collected in a clean sterile glass tube for screening for transfusion-transmitted diseases (HBV, HCV, HIV and malaria).

2. Samples were clearly identified with codes or names in order to avoid misinterpretation of results.

3. All the blood samples were subjected to the mandatory screening tests for detection of transfusion transmitted diseases (HBV, HCV, HIV and malaria) by the ELISA tests for antiHIV 1 and anti-HCV, HBsAg and malaria.

4. Then negative plasma samples are divided to 3 aliquots and stored at $-20^{\circ} \mathrm{C}$ for our study.

5. Screening for anti-HBcAg IgM by ELISA test for all 400 collected samples.

6. Then positive samples for anti-HBcAg IgM are confirmed by PCR for HBV DNA detection.

III. Methods of study:

(1) ELISA test for detection of anti HBc IgM:

Detection of anti HBV core IgM quantitatively was performed by using the anti- HBc IgM kit manufactured by DIA.PRO Diagnostic Bioprobes Srl Via Columella ${ }^{\circ}$ 31, 20128 Milano - Italy.

(2) Detection of HBV DNA by PCR technique for positive anti HBc IgM ELISA test:

DNA extraction protocol:

This protocol is for purification of viral nucleic acids from $200 \mu \mathrm{l}$ of plasma using the QIAamp MinElute Virus Spin Kit and a microcentrifuge (QIAGEN®, QIAamp®, QIAcube $\AA$, BioRobot ${ }^{\circledR}$, EZ1TM MinElute $\AA$ (QIAGEN Group); Corex ${ }^{\circledR}$ (Corning, Inc.); Eppendorf® (Eppendorf- Netheler-Hinz $\mathrm{GmbH}$ ). It was done by using universal primer pairs P1 (sense) ...5'-TCA CCA TAT TCT TGG GAA CAA GA-3' (2823-2845 nt) 1063bp , and S1-2(antisense).....5'CGA ACC ACT GAA CAA ATG GC-3' (704-685 nt). The reaction mixture contains $5 \mathrm{ul}$ of extracted DNA, $25 \mathrm{ul}$ of master mix, 5 Pmol of each primer completed to 50ul with distilled water. The thermal cycler was programmed at $95{ }^{\circ} \mathrm{C}$ for 10 minutes, followed by 40 cycles at $92{ }^{\circ} \mathrm{C}$ for $20 \mathrm{sec}$ (denaturation), $56{ }^{\circ} \mathrm{C}$ for $20 \mathrm{sec}$ (annealing), and $72^{\circ} \mathrm{C}$ for $1 \mathrm{~min}$ (extension) then at $72^{\circ} \mathrm{C}$ for 10 minutes. HBV genomic DNA and a negative sample were used as positive and negative controls, respectively from our microbiology lab. For the analysis of the PCR amplification, $10 \mu \mathrm{L}$ of the amplified DNA were run on $3 \%$ agarose gel after addition of $4 \mu \mathrm{L}$ of loading buffer .The presence of a1063-bp fragment indicated a positive result. In parallel with samples, a 100-bp DNA ladder 
was also run on the gels to estimate the molecular weight of DNA fragments in the gel.

\section{Statistical Analysis}

Data were collected, revised, coded and entered to the Statistical Package for Social Science (IBM SPSS) version 22. Qualitative variables were presented as number and percentages. The comparison between groups with qualitative data was done by using Chisquare test. The confidence interval was set to $95 \%$ and the margin of error accepted was set to $5 \%$. So, the pvalue was considered significant as the following: $\mathrm{P}>$ 0.05 was considered non-significant and $\mathrm{P}<0.05$ was considered Significant.

\section{RESULTS}

This study was conducted on 400 donated plasma samples of healthy blood donors and they were negative for all blood screening tests in blood bank (HBV, HCV, HIV and malaria). All donors showed normal blood pressure, normal liver function tests, and no history of jaundice or any liver disease which were done by blood bank. Baseline characteristics of the studied groups presented in tables (1 and 2).

The demographic data revealed that the patient ages ranged from 20-50 years. Three hundred and fifty two $352(88 \%)$ were males and $48(12 \%)$ were females, with male to female ratio was 7.3:1 respectively. Concerning age range and ratio between male and female according to this range, Donors of ages between 30-40 years constituted the largest proportion 172 (43\%). 144 $(37.25 \%)$ were males and $23(5.25 \%)$ were females. While age ranged from 20-30 was 123 (30.75\%), 114 $(28.5 \%)$ were males and $9(2.5 \%)$ were females and age from $40-50$ were $105(26.25 \%), 89$ (22.25\%) were males and $16(4 \%)$ were females. The majority of blood donors $312(78 \%)$ were from urban area, while the remaining $88(12 \%)$ were from rural area.

From a total selected 400 plasma samples of blood donors negative for $\mathrm{HBsAg}, 9 / 400(2.25 \%)$ were reactive for anti- HBcIgM, 7 (1.75) males versus $2(5 \%)$ females as shown in table (3). Concerning comparison between $\mathrm{HBc}$ IgM positive and negative samples from our selected group, 9/400 was positive, and 391/400 were negative. Seven males were positive and 344 were negative, while 2 female were positive and 46 were negative as shown in table (4).

These 9 reactive samples for anti HBcIgM, 6 of them show concentration more than $10 \mathrm{u} / \mathrm{ml}$ which indicate positive reaction while 3 was in the gray zone with a conc. between $5-10 \mathrm{u} / \mathrm{ml}$, PCR test for $\mathrm{HBV}$ (fig.1) was done for 9 anti $\mathrm{HBcIgM}$ positive samples for 9 samples were selected randomly from negative anti $\mathrm{HBcIgM}$ samples with the same age and sex of positive samples as control group. It was observed that four out of the 9 positive for anti-HBcIgM were positive for HBV DNA by PCR, representing a percentage of $1 \%$ while those in the grey zone was negative ( table 5 ).

Table (1): the demographic data of blood donors

\begin{tabular}{|l|c|c|c|c|c|c|}
\hline \multirow{2}{*}{ Age groups } & \multicolumn{2}{|c|}{ Total } & \multicolumn{2}{c|}{ Male } & \multicolumn{2}{c|}{ Female } \\
\hline $\mathbf{2 0 - 3 0}$ & No. & $\mathbf{\%}$ & No. & \% & No. & $\%$ \\
\hline $\mathbf{3 0 - 4 0}$ & 123 & $30.75 \%$ & 114 & $28.5 \%$ & 9 & $2.5 \%$ \\
\hline $\mathbf{4 0 - 5 0}$ & 172 & $43 \%$ & 149 & $37.25 \%$ & 23 & $5.25 \%$ \\
\hline Total & 105 & $26.25 \%$ & 89 & $22.25 \%$ & 16 & $4 \%$ \\
\hline
\end{tabular}

Table (2): The Distribution of blood donors according to residence

\begin{tabular}{|l|l|l|} 
& No. & $\%$ \\
\hline Urban & 312 & $78 \%$ \\
\hline Rural & 88 & $22 \%$ \\
\hline
\end{tabular}

Table (3): Distribution of positive sero reactive samples for anti HBcIgM among studied group

\begin{tabular}{|l|l|l|}
\hline & IgM & \% \\
\hline Total & $9 / 400$ & $2.25 \%$ \\
\hline Male & $7 / 400$ & $1.75 \%$ \\
\hline
\end{tabular}


Table (4): Comparison between anti HBcIgM positive and anti HBc IgM negative blood donors by sex distribution

\begin{tabular}{|c|c|c|c|c|c|c|}
\hline & \multicolumn{2}{|c|}{$\begin{array}{c}\text { Anti HBc IgM Positive } \\
\operatorname{IgM}(\text { no.=9) }\end{array}$} & \multicolumn{2}{|c|}{$\begin{array}{l}\text { Anti HbcIgM Negative } \\
\text { IgM (no.=391) }\end{array}$} & \multicolumn{2}{|c|}{ Chi square test } \\
\hline & No. & $\%$ & No. & $\%$ & $X^{2}$ & $P$ value \\
\hline Male & $7 / 9$ & $77.8 \%$ & $345 / 391$ & $88 \%$ & \multirow{2}{*}{0.852} & \multirow{2}{*}{0.356} \\
\hline Female & $2 / 9$ & $22.2 \%$ & $46 / 391$ & $12 \%$ & & \\
\hline
\end{tabular}

Table (5): Results of HBV-DNA by PCR in relation to results of anti-HBC IgM

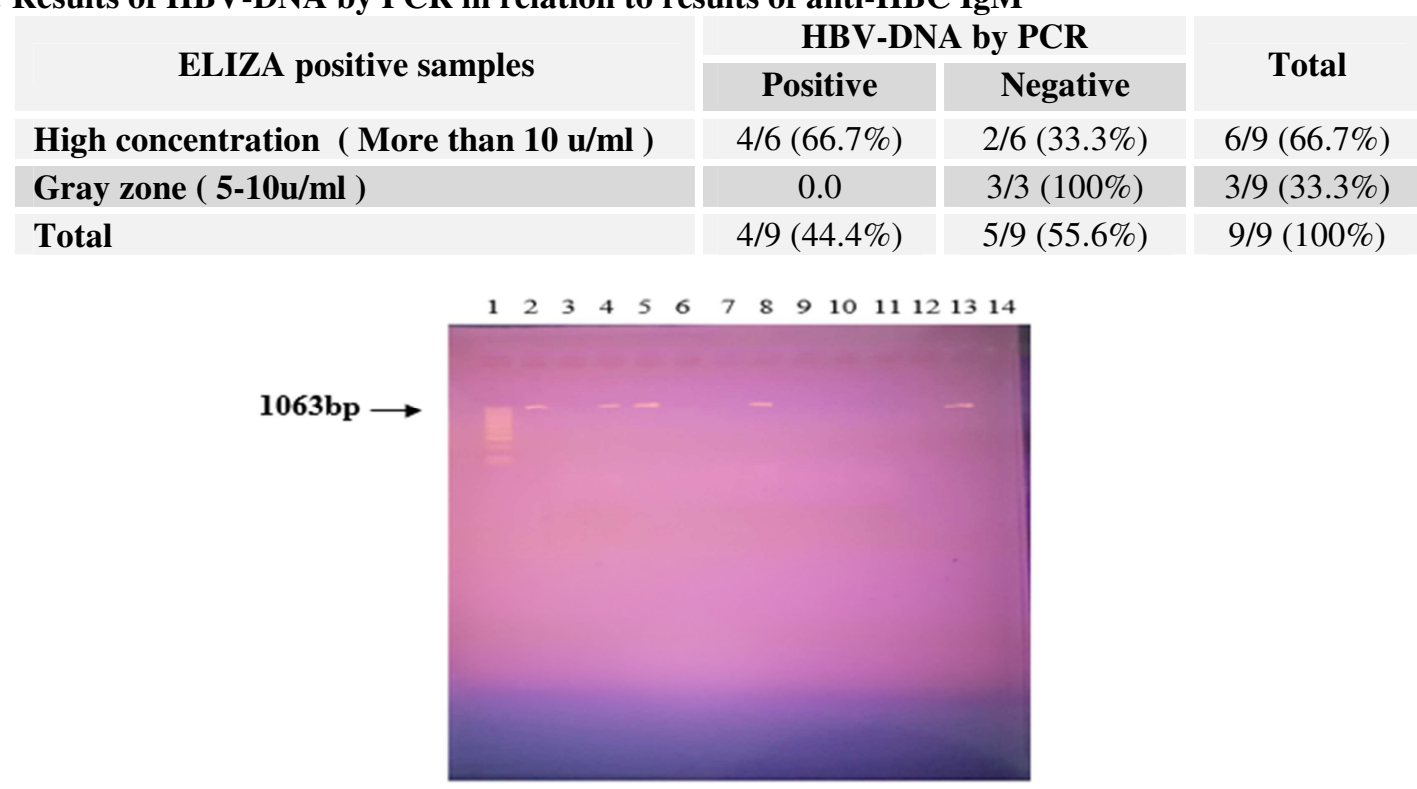

Fig. (1): HBV-DNA PCR An ethidum bromide stained agrose gel showing results of HBV-DNA PCR screening of collected sample which were HBsAg negative and anti-IgMHB c positive.

Lane 1: DNA ladder marker.

Lane $2,4,5$, and 8 positive samples showing the expected 1063-bp product.

Lane 13: positive control at 1063bp.

Lane 14: negative control.

\section{DISCUSSION}

In blood banks of many countries, HBsAg test is the only screening test to indicate HBV infection in donated blood. However, it does not rule out the risk of HBV transmission totally, because during the host serological response there is a phase during which the HBsAg cannot be detected although HBV infection is present. This phase is called the 'window period' which represents a carrier state of the disease. In addition, HBsAg is not detected in case of mutant strain therefore, transfusion of blood

collected from donors in these conditions may lead to post transfusion HBV infection in the recipient ${ }^{[13] \text {. }}$

As post transfusion $\mathrm{HBV}$ infection is a major problem especially in developing countries, finding a marker which would be indicative of HBV infection in HBs Ag negative cases is very important in blood banks. It is shown that $\mathrm{HBc} \mathrm{Ab}$ and nucleic acid tests are more effective in these cases. Since nucleic acid tests are expensive, anti- $\mathrm{HBc}$ antibodies has been found to be more suitable indicator in these conditions ${ }^{[14] .}$

The IgM class of the anti-HBc is the first to appear even late in incubation period and indicates a recent infection. So anti-HBc IgM is an excellent marker for HBV infection in HBsAg negative blood donors. While the IgG class of anti-HBc appears later and indicates a past infection. Individuals with antiHBcIgG may not be infectious and their blood is suitable for transfusion as they may have sufficiently high titres of anti- HBs which are protective in nature [10].

The prevalence of total anti-HBc in blood donors is proportional to the incidence of HBsAg in the general 
population. It is low in the Western countries as these countries have low incidence of HBsAg so, screening of donated blood in these countries by total anti-HBc is practical and they can discard such positive blood units without wastage ${ }^{[15]}$.

Several studied reported that detection of total anti$\mathrm{HBc}$ had contributed significantly in reduction of the incidence of post transfusion HBV infection amongst donors [16]. . On the other hand, blood banks in medium or high- endemic areas cannot depend on total anti $\mathrm{HBc}$ as a screening test for donated blood, as these countries have high prevalence of total anti$\mathrm{HBc}$. The reactive blood units for total anti $\mathrm{HBc}$ in these areas may not be infectious and these blood units are suitable for transfusion. Anti-HBc IgM seems to be more practical in these countries to see the infectivity status of $\mathrm{HBs} \mathrm{Ag}$ negative blood donors [17].

In our study we aimed to evaluate the role of anti$\mathrm{HBc} \operatorname{IgM}$ in blood donors negative for $\mathrm{HBsAg}$ in order to increase safety of donated blood. In this study, 400 blood donors negative for all routine screening tests in blood banks (HBsAg, HCV antibodies, HIVAbs and Treponema Abs), 352 (88\%) were males and $48(12 \%)$ were females with age ranges from 20-50 years. Quantitative analysis of anti-HBc IgM was done by "capture" enzyme immunoassay using DIAPRO Diagnostic Bioprobes kits. Positive samples for anti-HBc IgM were further tested for HBV-DNA by PCR.

This study revealed the following results, 9/400 $(2.25 \%)$ were reactive for anti-HBc IgM, 7 (1.75) males versus $2(.5 \%)$ females. The quantitative analysis for $\mathrm{HBc} \operatorname{IgM}$ revealed that 6 donors had antibody levels greater than 10.00 Paul Ehrlich International units per $\mathrm{mL}(\mathrm{PEI} \mathrm{U} / \mathrm{mL})$; these were considered positive. However, 3 donors in the grey area within the 5- to 10 -PEI $\mathrm{U} / \mathrm{mL}$ were considered border line. All these $9 \mathrm{HBc}$ IgM reactive samples were tested for DNA by PCR, 4/9 (1\%) were positive. The other $2+$ ve samples and all 3 samples which were in gray zone were negative for PCR

There was a close data to our study reported by a previous study in South Egypt Cancer Institute conducted on $180 \mathrm{HBsAg}$ negative blood specimens, were selected randomly for further testing for (anti HBcIgM, anti HBs antibody and HBV DNA testing). 7/180 (3.8\%) were positive for anti- HBcIgM,. While positive donors for anti-HBs antibody were 34/180 $(18.8 \%)$.Two specimens $(1.1 \%)$ out of 7 antiHBcIgM positive samples were positive for $\mathrm{HBV}$ DNA by PCR ${ }^{[18] \text {. }}$

Another study that conducted on 760 Egyptian blood donors were routinely screened for (HBsAg, HCVAb, HIV and Syphilis), accepted blood units (712) for donation were further tested for the presence of anti $\mathrm{HBc}-\mathrm{IgM}$ and HBV-DNA. These results were $(0.13 \%)$ HBc-IgM positive unit and 2/30 HBV DNA positive unit. Antibody should be tested routinely on all donated blood units as well as sensitive methods for detection of HBV (e.g. PCR) may be recommended in screening donated blood ${ }^{[19]}$.

There were two cross-sectional studies in Nigeria supporting the fact that screening blood donors for HBsAg does not rule out the risk of post transfusion HBV infection. The first one was in 2011, 92 blood donors were enrolled for this study screened for 5 different markers of $\mathrm{HBV}$ (HBsAg, anti HBsAg, HeAg, anti $\mathrm{HBeAg}$ and anti HbcIgM). HBsAg was detected in $18(19.6 \%)$, anti-HBs in 14 $(15.2 \%), \mathrm{HBeAg}$ and anti-HBe were detected in $4(8.9 \%)$ and $12(26.7 \%)$ respectively from 45 donors sampled. Anti- HBc IgM was found in 12 (13.0\%) cases , 7 of them sharing with other markers, while $5(5.4 \%)$ of the 92 donors had anti-HBcIgM as the only serological evidence of $\mathrm{HBV}$ infection, which represents high numbers from all infected cases [11]. The other study was conducted on 200 HBsAg- negative blood donors, then tested for HBV markers (HBeAg, anti-HBeAg, anti-HBs, total anti$\mathrm{HBc}$ and anti- $\mathrm{HBc} \operatorname{IgM})$. only 5 (2.5\%) were positive for anti-HBs. Sixty- five participants $(32.5 \%)$ were positive for total anti-HBc, indicating a past exposure to HBV. Overall, $8(4.0 \%)$ of the donors were found to be positive for anti-HBc IgM alone. Five (2.5\%) out of the $200 \mathrm{HBsAg-negative} \mathrm{blood} \mathrm{donors} \mathrm{were}$ positive for anti-HBs $(2.5 \%)^{[20]}$.

Another study by Lavanya of a total 200 blood donors were screened for the presence of HBsAg. Total anti-HBc, anti-HBc IgM and anti-HBs were done for $\mathrm{HBsAg}$ negative cases. The prevalence of HBsAg was $3.5 \%$ ( 7 cases) and $\mathrm{HBsAg}$ negative cases were 193, total anti-HBc $10.9 \%$ (22 cases), anti-HBc IgM 5.7\% (11 cases) and anti-HBs 3\% (6 cases). All the 6 anti-HBs positive donors were also found to be positive for total anti $\mathrm{HBc}$ indicating past infection, but the result of anti-HBc IgM indicates recent infection ${ }^{[21] .}$ An Indian study support the above results, 12232 healthy blood donors negative for $\mathrm{HBsAg}$ were screened for anti-HBc IgM, this study revealed a percentage of $(0.12 \%)$ reactive for anti$\mathrm{HBc}$ (IgM). This low percentage in comparison to other studies due to high number included in this study ${ }^{[22] \text {. }}$

According to study in India, a total of 2552 voluntary blood donors were studied for (HBsAg and anti HBcIgM) of which $47(1.84 \%)$ cases were HBsAg positive and 11 blood units were anti-HBcAg IgM 
positive, only one of these positive IgM was HBsAg positive and 10 were negative, giving a positivity rate of $0.39 \%$ amongst the $10 \mathrm{HBsAg}$ negative and anti$\mathrm{HBcAg}$ IgM reactive blood donors ${ }^{[23]}$. El-Zayadi and his coworkers study was conducted on 760 Egyptian healthy blood donors were screened according to routine practice for the presence of ( $\mathrm{HBsAg}, \mathrm{HCV}$ antibodies, HIVAbs and Treponema Abs). They reported that $48 / 760$ units $(6.3 \%)$ were rejected. The accepted blood units for donation were tested for the presence of total anti- $\mathrm{HBc}$ Abs.Positive units for total anti-HBc were further tested for HBV-DNA by PCR. Among the accepted blood units (712) for donation, prevalence of total anti-HBc was $78 / 712$ units (10.96\%). HBV-DNA was detected in $9 / 78$ $(11.54 \%)$ of the total anti-HBc-positive units and thus, occult HBV infection was detected in 9/712 $(1.26 \%)$ of the accepted blood donations ${ }^{[24]}$.

Another cross sectional study reported lower data, a total of $1026 \mathrm{HBsAg-negative} \mathrm{Egyptian} \mathrm{healthy}$ blood donors were tested for the presence of total anti-HBc . Anti- HBc-positive samples were subjected to PCR to confirm the presence of $\mathrm{HBV}$ DNA. They reported that 80/1026 (7.8\%) blood samples were found reactive to total anti-HBc and HBV DNA was detected in five $(4 \%)$ of these samples ${ }^{[25] .}$ Another study in El Fayoum conducted on 800 voluntary blood donors, negative for $\mathrm{HBsAg}$, $\mathrm{HCVAb}$ and HIV Ab. They were further screened for total anti $\mathrm{HBc}$ antibodies, then anti-HBc-positive samples were tested for anti-HBs and HBV DNA for total anti $\mathrm{HBc}$ only. Their result was 99/800 (12.37\%) anti-HBc-positive including 78 anti-HBs positive. The remaining 21 donors were anti-HBc alone, 2 of which $(9.52 \%)$ were HBV DNA-positive ${ }^{[26]}$.

Tamer and his coworkers in Al-Gharbia governorate, Tanta University reported 2 recent studies for high risk group of HBV transmission and reported higher pervelance data than our study. The first one included 90 regular Hemodialysis patients negative for $\mathrm{HBsAg}$ and anti-hepatitis $\mathrm{C}$ virus. Patients were investigated for anti- $\mathrm{HBc}$ and samples of anti-HBc-positive patients were tested for HBV-DNAPCR. The reported results were17/90 (18.9\%) +ve anti-HBc. Eleven anti-HBc-positive patients were anti-HBspositive. HBV-DNA was detected in seven of those 17 total anti-HBc-positive patients $(7.8 \%$ of all patients) ${ }^{[27]}$ The second study included 79 poly transfused patients negative for HBsAg, HBsAb, and anti $\mathrm{HBC} \mathrm{Ab}$. Patients were investigated for total anti-HBc and positive samples of total anti-HBc were tested for HBV-DNAPCR. Among the $79 \mathrm{HBsAg}$ negative sera, total anti-HBc was detected in 12 of 79 (15.19\%) cases. All total anti-HBc-positive sera were anti-HBs-negative. HBV-DNA was detected in five of $12\left(6.3 \%\right.$ of all patients) ${ }^{[28] .}$

\section{CONCLUSIONS}

To reach a completely safe blood transfusion; It is recommended that anti $\mathrm{HBc}$ mainly IgM class need to be implemented in Egypt as primary test in blood banks for detection of $\mathrm{HBs} \mathrm{Ag}$ negative blood donors. Also, HBV DNA need to a confirmatory test for anti $\mathrm{HBc}$ IgM positive cases and if they were positive regardless of anti-HBs titer, the blood should be discarded.

\section{Financial support}

No financial support from any institution only we depend on ourselves financially.

\section{Conflicts of interest}

The authors declare that there is no conflict of interest regarding the publication of this paper.

\section{REFRENCES}

1. Fayyadh T, Ma F. Comparative study of HBV, HCV and HDV serological markers among acute hepatitis B, chronic hepatitis B, apparently healthy patients. J Nurs Health Sci. 2017;6:79-85.

2. Teo EK, Lok AS. Epidemiology, transmission, and prevention of hepatitis B virus infection. UpToDate: June. 2006.

3. 3.Guidotti LG, Inverso D, Sironi L, Di Lucia $P$, Fioravanti J, Ganzer L et al. Immunosurveillance of the liver by intravascular effector CD8+ T cells. Cell. 2015 Apr 23;161(3):486-500.

4. Stasi C, Silvestri C, Berni R, Brunetto MR, Zignego AL, Orsini $\mathbf{C}$ et al . Clinical epidemiology of chronic viral hepatitis B: A Tuscany real-word large-scale cohort study. World journal of hepatology. 2018 May 27;10(5):409.

5. Niu B, Hann HW. Hepatitis B Virus-Related Hepatocellular Carcinoma: Carcinogenesis, Prevention, and Treatment. Updates in Liver Cancer. 2017 Apr 5:69.

6. Naghavi M, Abajobir AA, Abbafati C, Abbas KM, Abd-Allah F, Abera SF et al . Global, regional, and national age-sex specific mortality for 264 causes of death, 1980-2016: a systematic analysis for the Global Burden of Disease Study 2016. The Lancet. 2017 Sep 16;390(10100):1151-210.

7. Olotu AA, Oyelese AO, Salawu L, Audu RA, Okwuraiwe AP, Aboderin AO. Occult Hepatitis B virus infection in previously screened, blood donors in Ile-Ife, Nigeria: implications for blood transfusion and stem cell transplantation. Virology journal. 2016 Dec;13(1):76.

8. Lin H, Zhao H, Tang X, Hu W, Jiang N, Zhu S, Huang C. Serological patterns and molecular characterization of occult hepatitis b virus infection among blood donors. Hepatitis monthly. 2016 Oct;16(10). 
9. Nna E, Mbamalu C, Ekejindu I. Occult hepatitis B viral infection among blood donors in South-Eastern Nigeria. Pathogens and global health. 2014 Jul 1;108(5):223-8.

10. Al-Ezzi IH, Salman AD. Study of Some Serological Markers (Hbs Ag, Anti-Hbs and AntHbc Igm) for Detection of Occult Hepatitis B Virus Infection Among Blood Donors in Diyala Province. Age.;200:100-0.

11. Japhet MO, Adesina OA, Donbraye E, Adewumi MO. Hepatitis B core IgM antibody (anti-HBcIgM) among hepatitis B surface antigen (HBsAg) negative blood donors in Nigeria. Virology journal. 2011 Dec;8(1):513

12. Raimondo G, Allain JP, Brunetto MR, Buendia MA, Chen DS, Colombo M et al. Statements from the Taormina expert meeting on occult hepatitis B virus infection. Journal of hepatology. 2008 Oct $1 ; 49(4): 652-7$

13. Makroo RN, Chowdhry M, Bhatia A, Arora B, Rosamma NL. Hepatitis B core antibody testing in Indian blood donors: A double-edged sword!. Asian journal of transfusion science. 2012 Jan;6(1):10.

14. Allain JP. Global epidemiology of occult HBV infection. Ann Blood. 2017;2(7):1-3.

15. Candotti D, Laperche $S$. Hepatitis B virus blood screening: need for reappraisal of blood safety measures?. Frontiers in Medicine. 2018 Feb 21;5:29.

16. Alzahrani FM, Shaikh SS, Alomar AI, Acharya S, Elhadi N. Prevalence of Hepatitis B Virus (HBV) Among Blood Donors in Eastern Saudi Arabia: Results From a Five-Year Retrospective Study of HBV Seromarkers. Annals of laboratory medicine. 2019 Jan 1;39(1):81-5.

17. Esposito A, Sabia C, Iannone C, Nicoletti GF, Sommese L, Napoli C. Occult hepatitis infection in transfusion medicine: screening policy and assessment of current use of anti-HBc testing. Transfusion Medicine and Hemotherapy. 2017;44(4):263-72.

18. Badrawy H. , Bakry R. Anti-HBc and HBV-DNA detection in blood donors negative for hepatitis B virus surface antigen. American Journal of Molecular Biology 2013 ;3:62-66.

19. Essam Hassan Ibrahim, Mona Abdel Rahman, Soad N.Hamed, Ibrahim Abd El Hameed, Mohamed Abbas Shemis, Amal Saad Mostafa. Screening of Window HBV Infection among Egyptian Blood Donors. Journal of Drug Research.2007; 28: 129-135.

20. Available at https://www.researchgate.net/publication/235249325
Screening of Window HBV Infection among E gyptian_Blood Donors accessed on $22^{\text {nd }}$ May 2020.

21. Ogunfemi MK, Olawumi HO, Olokoba AB, Kagu MB, Biliaminu SA, Durowade KA et al. Prevalence of antibody to hepatitis B core antigen among hepatitis B surface antigen-negative blood donors in Ilorin, Nigeria: A cross-sectional study. Malawi Medical Journal. 2017;29(1):32-6.

22. Lavanya $\mathbf{V}$, Viswanathan $T$, Malar SA, Malarvizhi A, Moorthy K. Prevalence of hepatitis $B$ virus infection among blood donors with antibodies to hepatitis $\mathrm{B}$ core antigen. Int $\mathrm{J}$ Med Med Sci. 2012 Aug 31;4(6):128-37.

23. Shastry S, Bhat SS. Prevention of post-transfusion hepatitis by screening of antibody to hepatitis B core antigen in healthy blood donors. Mediterranean journal of hematology and infectious diseases. 2011;3(1).

24. Kumar H, Gupta PK, Jaiprakash M. The role of anti-HBc IgM in screening of blood donors. Medical Journal Armed Forces India. 2007 Oct 1;63(4):3502.

25. El-Zayadi AR, Ibrahim EH, Badran HM, Saeid A, Moneib NA, Shemis MA et al. Anti-HBc screening in Egyptian blood donors reduces the risk of hepatitis $\mathrm{B}$ virus transmission. Transfusion Medicine. 2008 Feb;18(1):55-61.

26. 25.Antar W, El-Shokry MH, Abd El Hamid WA, Helmy MF. Significance of detecting anti-HBc among Egyptian male blood donors negative for HBsAg. Transfusion Medicine. 2010 Dec;20(6):40913.

27. Abdelrazik AM, Abdelaziz HM. The role of Hepatitis B core antibody testing in improving blood safety in resource-limited countries study on voluntary blood donors Fayoum, Egypt. J Blood Disord Transfus. 2015;6(315):2.

28. Elbedewy TA, Elshweikh SA, Baiomy N. Prevalence and significance of hepatitis-B core antibodies among hepatitis B surface antigennegative Egyptian patients on hemodialysis in AlGharbia governorate. Tanta Medical Journal. 2016 Apr 1;44(2):33.

29. Elbedewy TA, Noreldin NM, Hamam SA. Prevalence and significance of hepatitis B core antibodies among hepatitis B surface antigennegative Egyptian polytransfused adult patients. The Egyptian Journal of Haematology. 2015 Jul 1; 40(3): 143 . 


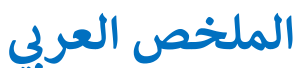

دور الكثف عن الجلوبيولين المناعي م لمستضد فيروس ب أللبي لمتبرعي الام سالبي المستضد السطي

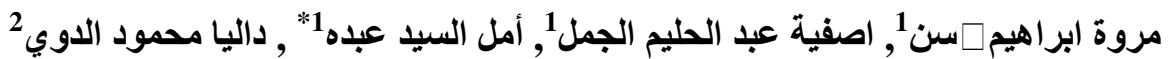

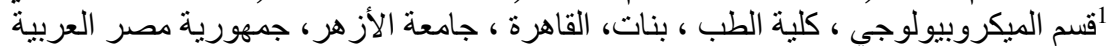

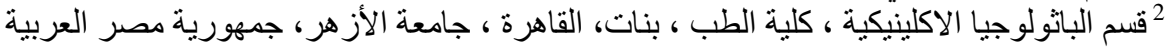

ملخص البحث:

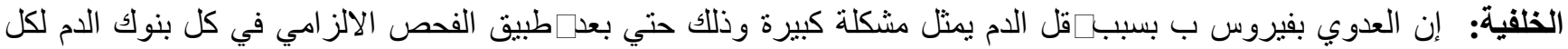

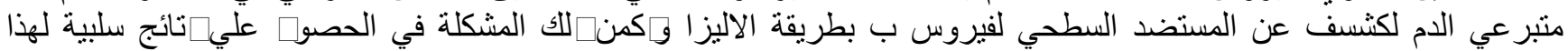

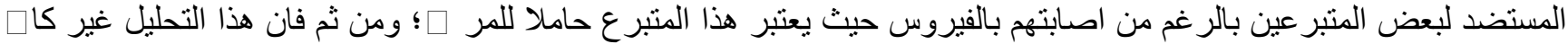

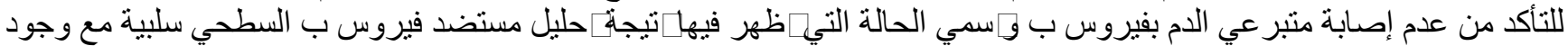

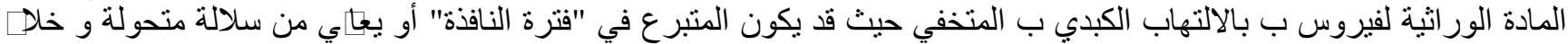

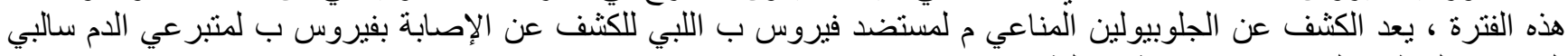
المسنضد السطحي لفيروس ب علامة مصلية مفيدة.

الهوف:ـ تعيين كفاءة الجلوبيولين المناعي م لمستضد فيروس ب اللبي للكثف عن الإصابة بفيروس ب لمتبر عي الام سالبي المستضد

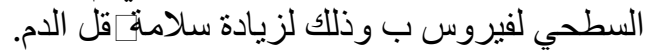

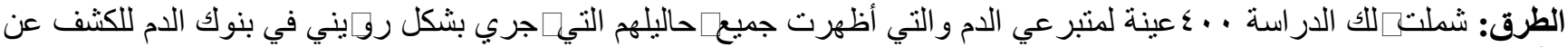

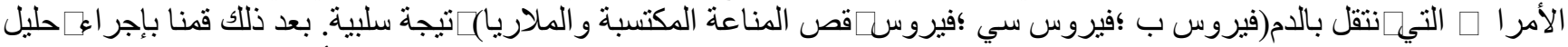

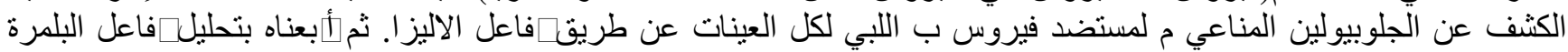

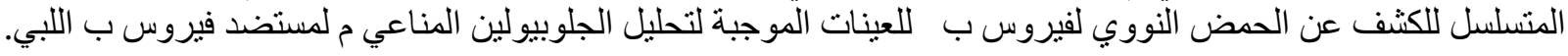

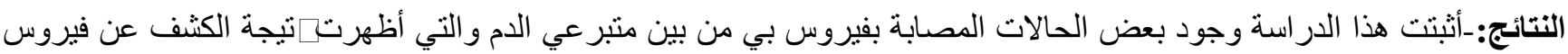

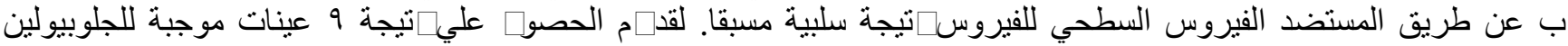

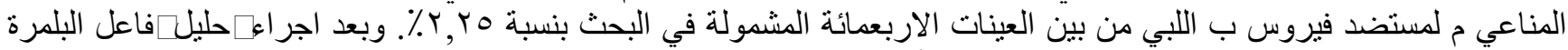

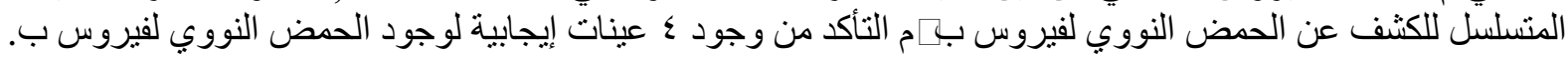

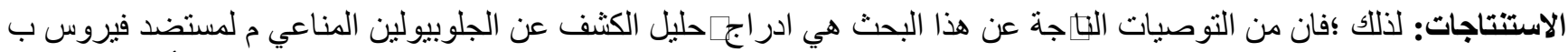

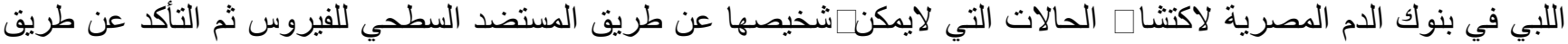
ـحليلهفاعل البلمرة المتسلسل للكثيف عن الحمض النووي لفيروس ب للعينات الموجبة لهذا التحليل.

الكلمات المفتامية: الجلوبين المناعي م , المستضد السطحي لفيروس الكبد ب , الحمض النووي لفيروس الكبد ب ,الفترة النافذة. الأسم: أمل النيّيد عبده ، قسم الميكروبيولوجي ـ ، كلية الطب ، بنات، القاهرة ، جامعة الأزهر ، جمهورية مصر العربية 